\title{
Cnicin from Centaurea benedicta $L$. is an active compound against skin inflammation in a mouse model
}

Orlando Vieira Sousa ( $\boldsymbol{\nabla}$ orlando.sousa@ufjf.edu.br)

Universidade Federal de Juiz de Fora https://orcid.org/0000-0001-8512-4464

Guilherme C. Gonçalves

Federal University of Juiz de Fora: Universidade Federal de Juiz de Fora

Lucas S. Queiroz

Universidade Federal de Juiz de Fora

Everton A. Ferreira

Universidade Federal de Juiz de Fora

Bruna C. S. Santos

Universidade Federal de Juiz de Fora

Ademar A. Silva Filho

Universidade Federal de Juiz de Fora

Alex G. Taranto

Universidade Federal de São João del-Rei: Universidade Federal de Sao Joao del-Rei

\section{Research Article}

Keywords: Centaurea benedicta, cnicin, inflammation, anti-inflammatory drugs, molecular docking

Posted Date: December 2nd, 2021

DOI: https://doi.org/10.21203/rs.3.rs-1124507/v1

License: (9) This work is licensed under a Creative Commons Attribution 4.0 International License.

Read Full License 


\title{
Cnicin from Centaurea benedicta $\mathbf{L}$. is an active compound against skin inflammation in a mouse model
}

Guilherme C. Gonçalves ${ }^{1}$, Lucas S. Queiroz ${ }^{1}$, Everton A. Ferreira ${ }^{1}$, Bruna C. S. Santos ${ }^{1}$, Ademar A. Silva Filho $^{2}$, Alex G. Taranto ${ }^{3}$, Orlando V. Sousa ${ }^{2, *}$

${ }^{1}$ Postgraduate Program in Pharmaceutical Sciences, Faculty of Pharmacy, Federal University of Juiz de Fora, Campus Universitário, São Pedro, 36036-900, Juiz de Fora, Minas Gerais, Brazil

${ }^{2}$ Department of Pharmaceutical Sciences, Faculty of Pharmacy, Federal University of Juiz de Fora, Campus Universitário, São Pedro, 36036-900, Juiz de Fora, Minas Gerais, Brazil

${ }^{3}$ Department of Biosystems Engineering, Federal University of São João del-Rei, Campus Dom Bosco, Praça Dom Helvécio, 74, Fábricas, 36301-160, São João del-Rei, Minas Gerais, Brazil

*Corresponding author: Orlando Vieira de Sousa

E-mail address: orlando.sousa@ufjf.edu.br

Tel: +55 32 21023893; +5532991453032; Fax: +553221023812.

\begin{abstract}
Centaurea benedicta L., commonly known as "cardo santo," is used as a tonic, antidepressant, anti-inflammatory, antibacterial, and antiseptic in traditional medicine. This study evaluated the topical anti-inflammatory potential of an extract (ECB) and cnicin (CNI) from $C$. benedicta leaves in a mouse model. Activity was assessed using the ear edema method with croton oil, phenol, capsaicin, and histamine as phlogistic agents. Myeloperoxidase (MPO), N-acetyl- $\beta$-D-glucosaminidase (NAG), nitric oxide (NO), tumor necrosis factor $\alpha$ (TNF- $\alpha$ ), interleukin 6 (IL-6), and histopathology were assessed as markers of edema/inflammation. Interaction profiles between CNI and cyclooxygenase-1 and -2 , induced nitric oxide synthase, and glucocorticoid receptor were examined with molecular docking. Twenty-four $h$ after induction of inflammation, ECB and CNI treatments decreased the thickness and weight of ears by 39.59\%94.72\%. MPO, NAG, NO, TNF- $\alpha$, and IL-6 levels were also reduced. Histopathological, treatments reduced edema thickness, leukocytes, and vasodilation. Inflammation induced by phenol and histamine was inhibited by ECB and CNI, and ECB suppressed capsaicin-induced inflammation. CNI interacts with cyclooxygenase-1 and nitric oxide synthase through conventional hydrogen bonds, indicating inhibition of these enzymes. ECB and its compound cnicin reduce chemically-induced inflammation in mice suggesting new possibilities for the treatment of diseases associated with dermal inflammatory processes.
\end{abstract}

Keywords Centaurea benedicta; cnicin; inflammation; anti-inflammatory drugs; molecular docking

$\begin{array}{ll}\text { Abbreviations } & \\ \text { AA } & \text { Arachidonic acid } \\ \text { CNI } & \text { Cnicin } \\ \text { COX-1 } & \text { Cyclooxygenase-1 } \\ \text { COX-2 } & \text { Cyclooxygenase-2 } \\ \text { Dexa } & \text { Dexamethasone } \\ \text { ECB } & \text { Extract from } C \text {. benedicta } \\ \text { IL-6 } & \text { Interleukin } 6 \\ \text { i-NOS } & \text { Induced nitric oxide synthase } \\ \text { INDO } & \text { Indomethacin } \\ \text { MPO } & \text { Myeloperoxidase } \\ \text { NAG } & \text { N-acetyl- } \beta \text { - } D \text {-glucosaminidase } \\ \text { NO } & \text { Nitric oxide } \\ \text { TNF- } \alpha & \text { Tumor necrosis factor } \alpha\end{array}$

Acknowledgments We thank the Laboratório Multiusuário de Bioprodutos e Bioprocessos (CENTRALBIO/UFJF) for HPLC analysis. We are also grateful to Éder Luis Tostes, Jésus de Paula Sarmento, Lorena Rodrigues Riani (NIPPAN), Lívia Mara Silva, and Carolina Gasparetto Silva for the technical support.

\section{Introduction}

Skin diseases are a major cause of disability in patients due to pain, deformity, psychological impact, and even death. These impacts can impair social relationships and productive capacity (Zhang et al. 2019; Karimkhani et al. 2017). Skin is susceptible to viral, bacterial, and fungal infections, sunlight, 
allergens, and irritants (Karimkhani et al. 2017). Skin disorders may be simple and intermittent (skin rashes and redness), or chronic (psoriasis, rosacea, dermatitis, and acne) (Hahnel et al. 2017). Psoriasis, for example, causes lesions on the body, leading to social isolation, and has been linked to hypertension, diabetes, depression, anxiety, weight gain, and obesity, among other conditions (Rendon and Schäkel 2019). Psoriasis also affects joints and increases the risk of heart attack and stroke (Jindal and Jindal 2018). Despite different etiology, stimulation of inflammatory pathways, with the participation of enzymes and substrates, and several chemical mediators, such as histamine, serotonin, kinins, eicosanoids, platelet activation factor, nitric oxide, necrosis factor tumor, and interleukins are common to skin disease (Pasparakis et al. 2014). Lesions associated with immune dysregulation are difficult to treat due to limitations in the use of systemic immunosuppressants. These drugs cause adverse effects, such as gastric irritation, ulceration, hemorrhage, kidney failure, interstitial nephritis, headache, thrombocytopenia, hemolytic anemia, asthma, exacerbation, rash, angioedema, and pruritus, that restrict prolonged use (Aljebab et al. 2017). Natural products are often less toxic and safer than immunosuppressants and are the subject of the current search for new pharmaceuticals (Shedoeva et al. 2019). In addition, plant extracts have advantages because they are phytocomplexes with varied chemical compositions that can act through different mechanisms on inflammatory pathways.

C. benedicta L. (Asteraceae family), also known as Cnicus benedictus or Cardus benedictus, is commonly called "cardo santo" and "cardo bento." The plant displays several medically useful properties, including use as an anti-inflammatory, for healing, as an antipyretic and appetite stimulant, for increasing bile secretion, strengthening the liver, and decreasing jaundice (Ulbricht et al. 2008). A paste made from the plant is used to treat ulcers (Djamila et al. 2013), and a tonic made from aerial parts of the plant increases appetite and gastrointestinal secretion (Tiwana et al 2021). The species has also been studied for its antimicrobial and antineoplastic effects (Al-Snafi 2016). Further, a variety of chemical compounds is found in $C$. benedicta, especially sesquiterpene lactones (e.g., cnicin). These compounds are likely responsible for its therapeutic properties. Other compounds have also been chemically characterized, including polyacetylene, triterpenoids, lignans, flavonoids, tannins, essential oils, phenolic compounds, saponins, alkaloids, starch, glycosides, and coumarins (Al-Snafi 2016; Can et al. 2017).

Cnicin (Fig. 1) is a sesquiterpene lactone identified from the genus Centaurea (Mizuno and Usuki 2018). This compound shows allelopathic, antibacterial, cytotoxic, anti-myeloma, schistosomicidal, and cytostatic potential (Al-Snafi 2016; Bach et al. 2011; Queiroz et al. 2021). Cnicin induced cytotoxicity in human macrophages (Bach et al. 2011) and epithelial cells (LLC-PK1), human malignant melanoma (SKMEL), and human ductal carcinoma (BT-549) (Erel et al. 2011). Cnicin also inhibited proliferation in multiple myeloma, and induced cell death in cell lines of primary and hematopoietic myeloma; stromal and endothelial cells were not affected (Jöhrer et al., 2012). Mechanisms of action are associated with activation of caspases, accumulation of reactive oxygen species and negative regulation of the nuclear factor kappalight-enhancer $(\mathrm{NF}-\mathrm{kB})$ of activated $\mathrm{B}$ cells. Negative regulation of Pim-2, a serine/threonine kinase responsible for in vitro survival of myeloma cells is also observed (Karimkhani et al. 2017). Moreover, cnicin inhibits nuclear transcription factor kappa $\mathrm{B}(\mathrm{NF}-\kappa \mathrm{B})$ and inducible oxide nitric synthase (i-NOS) (Al-Snafi 2016, Erel et al., 2011), and could impede the viral replication of SARS CoV-2 (Alhadrami et al. 2021). C. benedicta is a promising source of anti-inflammatory agents and this study evaluated the topical anti-inflammatory activity of ECB and CNI to identify new therapeutic options for treating inflammatory processes in the skin. The research may augment current options for treatment of debilitating skin disease.

Fig. 1 Chemical structure of cnicin.

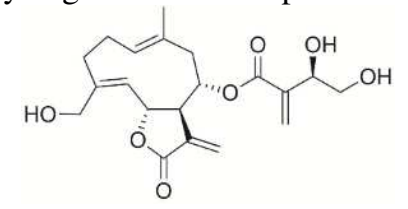

\section{Materials and Methods}

Plant material

C. benedicta leaves were collected at the Medicinal Garden $\left(21^{\circ} 46^{\prime} 29.49^{\prime \prime S}, 43^{\circ} 22^{\prime} 06.26^{\prime \prime W}\right)$ of the Faculty of Pharmacy of the Federal University of Juiz de Fora (FF/UFJF), Juiz de Fora, Minas Gerais, Brazil, on August 16, 2017. A voucher specimen (CESJ number 71393) identified by Dr. Fátima Regina Gonçalves Salimena was deposited in the Herbarium Leopoldo Krieger of UFJF.

Rinsed leaves of $C$. benedicta L. (ECB) were extracted with dichloromethane:ethanol (9:1 v/v). Isolation and identification of CNI followed previously described methods (Queiroz et al. 2021). The purity of cnicin was estimated to be greater than $95 \%$ by HPLC-DAD analysis (Queiroz et al. 2021). All phytochemical procedures were carried out at the Nucleus for Identification and Research of Natural Active 
Principles - NIPPAN, Faculty of Pharmacy, Federal University of Juiz de Fora. For this study, ECB and CNI were provided by Dr. Ademar Alves da Silva Filho, coordinator of NIPPAN.

Chemicals

Drugs and reagents used in this study included: croton oil, arachidonic acid (AA), phenol, capsaicin (8-methyl-N-vanillyl-6-nonenamide), histamine, dexamethasone, dexchlorpheniramine, indomethacin (Sigma-Aldrich ${ }^{\circledR}$ Co., St. Louis, MO, USA), ethanol, dichloromethane, and acetone (Vetec ${ }^{\circledR}$ Química Farm Ltda, Rio de Janeiro, RJ, Brazil), and ketamine chloride and xylazine chloride (Syntec ${ }^{\circledR}$, Hortolândia, SP, Brazil).

Animals

Male Swiss mice, 30-35 days old, and weighing 25-30 g, were supplied by the Central Animal Facility/UFJF. Experiments were carried out at the Biomedicinal Chemistry and Applied Pharmacology Laboratory of FF/UFJF. Animals were housed in plastic cages $(47 \times 34 \times 18 \mathrm{~cm})$ at temperatures between $22^{\circ} \mathrm{C}-24^{\circ} \mathrm{C}$, in a $12 / 12 \mathrm{~h}$ light cycle, with food and water ad libitum. Animals were acclimated for $24 \mathrm{~h}$ before use. Experiments followed guidelines of the Brazilian College of Animal Experimentation (COBEA) after approval by the Ethics Committee on Animal Use/UFJF (protocol number 022/2018).

Croton oil-induced mouse ear edema

As recommended by Colorado et al. (1991), with minor modifications, ear edema was induced with croton oil $(2.5 \% \mathrm{v} / \mathrm{v}$ in $20 \mu \mathrm{L}$ of acetone) applied on the inner surface of the right ear, while the left ear received $20 \mu \mathrm{L}$ of acetone. After $15 \mathrm{~min}$, the right ear was treated with $20 \mu \mathrm{L}$ of ECB $(0.1,0.5$, and 1.0 $\mathrm{mg} /$ ear), CNI (0.1, 0.5, and $1.0 \mathrm{mg} /$ ear), dexamethasone $(0.1 \mathrm{mg} /$ ear) and saline (negative control group). A basal group (non-inflamed and untreated) and another treated with vehicle alone were also included. A digital micrometer (Digital Micrometer IP400 to $25 \mathrm{~mm} \times 0.001 \mathrm{~mm}$ Digimess 110.284-NEW) was used to measure the thickness of the ears $(\mu \mathrm{m})$ after six and $24 \mathrm{~h}$ to assess the development of edema. Weight was quantified $24 \mathrm{~h}$ after treatment. An anesthetic overdose [ketamine $(300 \mathrm{mg} / \mathrm{kg})$ and Xylazine (30 $\mathrm{mg} / \mathrm{kg}$ )] was used for euthanasia. Ear fragments (right and left) were removed using a metallic punch (Richter, $0.6 \mathrm{~mm}$ ) and weighed on an analytical balance (AY220, Shimadzu ${ }^{\circledR}$ ). The difference in thickness $(\mu \mathrm{m})$ and weight $(\mathrm{mg})$ between the right and left ears was taken as a measure of edema. Weighed ear fragments were used for assessing inflammatory markers and for histopathology.

Inflammatory markers

\section{Supernatant preparation}

The method of De Young et al. (1989), with minor modification, was used to prepare tissues for analysis. Three ear fragments $(6 \mathrm{~mm})$ were crushed in a porcelain gral in an ice bath with sodium phosphate buffer $(1 \mathrm{~mL}, 80 \mathrm{mM}, \mathrm{pH} 5.4)$ containing hexadecyltrimethylammonium bromide $(0.5 \%)$. This material was transferred to a test tube and disrupted with an Ultra Cleaner 1600 ultrasound (Unique ${ }^{\circledR}$ ) for 10 min. Samples were then centrifuged at $3000 \mathrm{rpm}$ for $10 \mathrm{~min}$ and supernatants collected and used for the analysis of total protein, myeloperoxidase (MPO), $\mathrm{N}$-acetyl- $\beta$-D-glucosaminidase (NAG), nitric oxide (NO), tumor necrosis factor $\alpha$ (TNF- $\alpha$ ), and interleukin 6 (IL-6).

\section{Total protein dosage}

The method recommended by Lowry (1951) and modified by Sargent (1987) was used to measure total protein concentrations. Forty $\mu \mathrm{L}$ of supernatant, $360 \mu \mathrm{L}$ of distilled water and $2 \mathrm{~mL}$ of reaction mixture [1.960 mL of alkaline solution $\left(1 \mathrm{~g}\right.$ of $\mathrm{NaOH}$ plus $5 \mathrm{~g}$ of $\mathrm{Na}_{2} \mathrm{CO}_{3}$ in $250 \mathrm{~mL}$ of water, $20 \mu \mathrm{L}$ of copper tartrate and $20 \mu \mathrm{L}$ of copper sulfate)] were mixed in test tubes. After $10 \mathrm{~min}, 200 \mu \mathrm{L}$ of Folin solution (1:5) was added and tubes were allowed to sit for $30 \mathrm{~min}$. Absorbance at $660 \mathrm{~nm}$ was then measured using a Shimadzu ${ }^{\circledR}$ UV-VIS 1800 spectrophotometer). Distilled water was used as a blank. A standard curve of albumin $1.0 \mathrm{mg} / \mathrm{mL}(80-400 \mu \mathrm{g} / \mathrm{mL})$ was also established.

\section{Myeloperoxidase assay}

Assays used of the method from Bradley et al. (1982), modified by De Young et al. (1989). Microplates (96-well, $\mathrm{n}=3$ ) with $70 \mu \mathrm{L}$ of supernatant, $35 \mu \mathrm{L}$ of 3.3', 5.5'-tetramethylbenzidine $(1.6 \mathrm{mM}$ in dimethylsulfoxide) and $105 \mu \mathrm{L} 0.003 \%$ hydrogen peroxide (v/v, diluted in $80 \mathrm{mM}$ sodium phosphate buffer, $\mathrm{pH}$ 5.4) were incubated at $37^{\circ} \mathrm{C}$ for $5 \mathrm{~min}$. One hundred and forty $\mu \mathrm{L}$ of $4 \mathrm{M}$ sulfuric acid at $4{ }^{\circ} \mathrm{C}$ was added to each well to stop the reaction. Absorbance was measured at $450 \mathrm{~nm}$ in a microplate reader, using distilled water as blank. Results are expressed as optical density/mg of protein (OD/mg of protein). 


\section{$N$-Acetyl- $\beta$-D-glucosaminidase assay}

Using the method of Sánchez and Moreno (1999), triplicate $200 \mu \mathrm{L}$ aliquots of supernatant were added to 96 -well plates along with $50 \mu \mathrm{L} 2.24 \mathrm{mM}$ p-nitrophenyl-N-acetyl- $\beta$-D-glucosamine in citrate buffer $/ 100 \mathrm{mM}$ sodium phosphate ( $\mathrm{pH} 4.5$ ). Plates were incubated at $37^{\circ} \mathrm{C}$ for $10 \mathrm{~min}$ and the reaction was stopped with $100 \mu \mathrm{L} 200 \mathrm{mM}$ glycine buffer (pH 10.6). Absorbance at $405 \mathrm{~nm}$ was recorded with a microplate reader and results expressed as optical density/mg of protein $(\mathrm{OD} / \mathrm{mg}$ of protein).

\section{Nitric oxide assay}

Nitric oxide (NO) levels were analyzed indirectly by measuring nitrite concentrations $\left(\mathrm{NO}^{2-}\right)$ using the Griess colorimetric method (Green et al. 1982). Griess reagent consists of a mixture (1:1) of sulfanilamide $(1 \%, \mathrm{w} / \mathrm{v})$ and $\alpha$-naphthyl-ethylenediamine $(0.1 \%, \mathrm{w} / \mathrm{v})$ in $5 \%$ phosphoric acid. Homogenates were prepared from ear fragments with $3000 \mu \mathrm{L}$ of buffered saline (PBS - pH 7.2) and crushed for about $60 \mathrm{~s}$. The homogenate was collected and stored in microtubes at $-80^{\circ} \mathrm{C}$. The assay was performed in triplicate using a microplate with homogenate $(100 \mu \mathrm{L})$ and Griess reagent $(100 \mu \mathrm{L})$. The microplate was incubated at room temperature for $20 \mathrm{~min}$. Absorbance at $540 \mathrm{~nm}$ was measured with a microplate reader. Nitrite concentrations were calculated from a standard curve using sodium nitrite solution $\left(\mathrm{NaNO}_{2}\right)(3.12-$ $200 \mu \mathrm{M})$. Results are expressed as $\mu \mathrm{Ms}$.

\section{Cytokine assays}

TNF- $\alpha$ and IL- 6 levels were assessed using the homogenate obtained from ear fragments after centrifugation. Kits that use monoclonal antibodies for pro-inflammatory cytokines, TNF- $\alpha$ and IL-6, were used. Standards with known concentrations were employed following manufacturer's instructions (Peprotech, Rocky Hill, New Jersey, USA). Sensitivities of kits were TNF- $\alpha$ (10-2500 pg/mL) and IL-6 (3-3400 pg/mL). Absorbance at $405 \mathrm{~nm}$ was measured with a microplate reader. Cytokine levels were estimated by interpolation from standard curves according to the manufacturer's instructions. Values are expressed in $\mathrm{pg} / \mathrm{mL}$.

\section{Histopathological analysis}

Ear fragments (6 mm discs) were placed in 10\% formaldehyde (v/v) and fixed in 70\% ethanol for $24 \mathrm{~h}$ (Chibli et al. 2014). Fragments were then dehydrated, blocked in paraffin and transverse sections cut with a microtome $(5 \mu \mathrm{m})$ (TBS Cut 4060 Rotary Microtome, Thermo Fisher Scientific Inc.). Sections were stained with hematoxylin-eosin and fixed on glass slides for microscopic analysis (BX 51 Olympus microscopy, Olympus Optical Co., LTD; magnification: 20×). Representative areas of tissue were selected and Image-Pro ${ }^{\circledR}$ Plus software (version 6.0, Media Cybernetics, Inc.) used to capture images.

Arachidonic acid- and phenol-induced mice ear edema

Ear edema was induced in mice $(n=8)$ by topical administration on the inner surface of the right ear using arachidonic acid (2.0 mg in $20 \mu \mathrm{L}$ of acetone/ear) (Young et al. 1984) and phenol (10\% v/v in 20 $\mu \mathrm{L}$ of acetone/ear) ( $\mathrm{Lim}$ et al. 2004), while the left ear received $20 \mu \mathrm{L}$ of vehicle acetone. Fifteen (arachidonic acid and phenol) after induction of edema, the right ear was topically treated with ECB and CNI $(0.1,0.5$ and $1.0 \mathrm{mg} /$ ear in $20 \mu \mathrm{L}$ of acetone), indomethacin $(2.0 \mathrm{mg} /$ ear in $20 \mathrm{~mL}$ of acetone, positive control for AA), dexamethasone ( $0.1 \mathrm{mg} / \mathrm{ear} 20 \mu \mathrm{L}$ of acetone, positive control for phenol) and acetone (20 $\mathrm{mL} / \mathrm{ear}$, negative control). The animals were euthanized with ketamine $(300 \mathrm{mg} / \mathrm{kg}$, i.p.) and xylazine (30 $\mathrm{mg} / \mathrm{kg}$, i.p.) $1 \mathrm{~h}$ after AA and $2 \mathrm{~h}$ after phenol application for the removal of ear fragments (6 mm discs) using a metal punch (Richter, São Paulo, SP, Brazil). After euthanasia, the ear edema was evaluated by means of increase in ear thickness $(\mu \mathrm{m})$ and weight $(\mathrm{mg})$.

Capsaicin-induced mouse ear edema

As described by Silva et al. (2018), with minor modifications, right ears of eight mice per group $(\mathrm{n}=8)$ were treated with ECB $(0.1,0.5$ and $1.0 \mathrm{mg} / \mathrm{ear})$, CNI $(0.1,0.5$ and $1.0 \mathrm{mg} / \mathrm{ear})$, dexamethasone $(0.1$ $\mathrm{mg} / \mathrm{ear}$ ) and $20 \mu \mathrm{L}$ of saline (negative control group). After $1 \mathrm{~h}$, edema was induced with $20 \mu \mathrm{L}$ of capsaicin $(0.01 \mathrm{mg} / \mu \mathrm{L}, \mathrm{v} / \mathrm{v}$, diluted in acetone) was applied to the right ear; the left ear received $20 \mu \mathrm{L}$ of acetone. Ears from basal and vehicle-only control mice were again included. After 30 min, animals were euthanized with an anesthetic overdose. An external digital micrometer was used to measure thickness (mm), and weights of ear fragments were determined using an analytical balance (AY220, Shimadzu ${ }^{\circledR}$ ). Measurements of edema by thickness and weight were calculated by differences between right and left ears.

Histamine-induced mouse ear edema

Using the method described by Brand et al. (2002), with modifications, mice were divided into groups of eight animals and treated with ECB $(0.1,0.5$ and $1.0 \mathrm{mg} / \mathrm{ear}), \mathrm{CNI}(0.1,0.5 \mathrm{and} 1.0 \mathrm{mg} / \mathrm{ear})$, 
dexamethasone ( 0 and $1.0 \mathrm{mg} / \mathrm{ear})$, dexchlorpheniramine $(0.1 \mathrm{mg} / \mathrm{ear})$ and saline $(2 \mu \mathrm{L}$, negative control group). Basal and vehicle-only groups were included. Thirty minutes after treatment, animals were anesthetized $(100 \mathrm{mg} / \mathrm{kg}$ ketamine and $10 \mathrm{mg} / \mathrm{kg}$ xylazine $)$ and $10 \mu \mathrm{L}$ of histamine $(100 \mu \mathrm{g} / \mathrm{mL})$ in saline was applied intradermally in the right ear using a 30G hypodermic needle. In the left ear, the same volume of saline was administered. The digital micrometer was used to measure ear thickness ( $\mathrm{mm}$ ) every $15 \mathrm{~min}$ up to $90 \mathrm{~min}$. After $90 \mathrm{~min}$, animals were euthanized with an anesthetic overdose and ear fragments were removed and edema assessed using differences between the right and left ears.

\section{Molecular modeling}

Two-dimensional structures of ligands were drawn in MarvinSketch (16.7.4), and threedimensional structures generated using the Clean in 3D function. Structural geometry was refined by semiempirical calculations with MOPAC 2012 applying the PM7 method. 3D crystallographic coordinates (COX-1, code 1EQG; COX-2, code 5IKV; i-NOS, code 1R35; and glucocorticoid receptor, code 1P93) were obtained from the Protein Data Bank (Stewart 2014). Molecular docking used AutoDockVina 1.1.2 simulation boxes (Trott and Olson 2010). Docking calculations were obtained and crystallographic ligands validated by redocking. Discovery Studio v. 4.52016 analyzed interactions for molecular recognition.

Statistical analysis

Results are presented as means \pm S.E.M. Analysis of variance (ANOVA) followed by post-hoc Student-Newman-Keuls tests were used to assess significance $(p<0.05)$ using GraphPad Prism ${ }^{\circledR} 7.0$ program.

\section{Results}

Effects of ECB and CNI on croton oil-induced mouse ear edema

Topical application of croton oil increased the thickness and weight of ears (Fig. 2A, 2B and 2C). Six hours after treatment with ECB $(60.67,60.73$, and $60.40 \%)$ or CNI $(51.29,69.71$, and $72.90 \%)$ edema was reduced in a dose-dependent manner $(0.1,0.5$ and $1.0 \mathrm{mg} / \mathrm{ear})$ compared with negative controls (Fig. 2A). Similarly, 24 hours after treatment with ECB (59.76 to 82.22\%) or CNI (39.59 to 69.79\%) thickness was also reduced (Fig. 2B), while ECB (65.69 to 80.04\%) or CNI (90.22 to $94.53 \%)$ decreased ear weight in a dose-dependent manner (Fig. 2C). CNI doses of 0.5 and $1.0 \mathrm{mg} /$ ear effects were not significantly from Dexa in reducing edema six hours after administration (Fig. 2A) (p<0.05). After $24 \mathrm{~h}, \mathrm{ECB}(0.5$ and 1.0 $\mathrm{mg} / \mathrm{ear}$ ) and CNI (1.0 mg/ear) reduced thickness of ears to the same extent as Dexa (Fig. 2B). ECB (0.1, 0.5 , and $1.0 \mathrm{mg} / \mathrm{ear})$ showed efficacy similar to Dexa, and CNI $(0.1,0.5$, and $1.0 \mathrm{mg} / \mathrm{ear})$ was even more active ( $\mathrm{p}<0.01$ or $\mathrm{p}<0.001)$ (Fig. 2C).

Ears from negative control animals showed MPO activity increased by $189 \%$ compared with basal group mice (Fig. 2D). ECB (19, 28, and 59\% at doses of $0.1,0.5$, and $1.0 \mathrm{mg} / \mathrm{ear}$, respectively) or CNI (62, 72 , and $65 \%$ at respective doses of $0.1,0.5$, and $1.0 \mathrm{mg} / \mathrm{ear}$ ) reduced MPO levels in comparison to negative controls. Dexa produced 54\% inhibition of MPO activity. ECB impact (1.0 mg/ear) was similar to Dexa (p $<0.05)$. Effects of CNI (0.1 and $1.0 \mathrm{mg} / \mathrm{ear})$ were statistically equivalent to effects of $1.0 \mathrm{mg} / \mathrm{ear}$ of ECB. CNI $(0.1,0.5$, and $1.0 \mathrm{mg} /$ ear) was more potent than Dexa in inhibiting MPO activity $(\mathrm{p}<0.05 ; \mathrm{p}<0.01$; $\mathrm{p}<0.001)$.

NAG activity increased significantly in ears of negative control group mice compared with the basal group (Fig. 2E). ECB exacerbated inhibition of NAG activity by $26 \%(0.1 \mathrm{mg} / \mathrm{ear}), 20 \%(0.5 \mathrm{mg} / \mathrm{ear})$ and $11 \%$ (1.0 mg/ear) compared with negative controls. CNI reduced NAG activity by 47 (0.1 mg/ear), 28 $(0.5 \mathrm{mg} / \mathrm{ear})$ and $50 \%$ (1.0 mg/ear). Dexa was also effective in inhibiting NAG levels (26\%). CNI doses of 0.1 and $1.0 \mathrm{mg} /$ ear were more potent than Dexa $(\mathrm{p}<0.001)$, and ECB, $0.1 \mathrm{mg} / \mathrm{ear}$, was as effective as CNI (0.5 mg/ear).

Nitric oxide (NO) levels were high in ears of negative control mice (Fig. 2F). ECB (0.1, 0.5, and $1.0 \mathrm{mg} / \mathrm{ear}$; 48, 74 and $62 \%$, respectively) or CNI (0.1, 0.5, and $1.0 \mathrm{mg} / \mathrm{ear} ; 78,97$ and 80\%, respectively) reduced these NO levels ( $p<0.001)$. As expected, Dexa reduced NO $(23 \%)$, and ECB and CNI were more potent inhibitors $(\mathrm{p}<0.001)$ than Dexa (Fig. 2F).

Using doses of $0.1,0.5$, and $1 \mathrm{mg} /$ ear, ECB $(7.41 \%, 27.83 \%$ and $51.70 \%$, respectively) and CNI (6.03, 11.49 and $14.80 \%$, respectively) also reduced TNF- $\alpha$ expression $(p<0.01$ or $p<0.001$; Fig. 4G), and IL-6 expression was inhibited by ECB $(13.71,29.16$ and $55.12 \%$, respectively; $p<0.01$ or $p<0.001)$ and CNI (8.40, 18.60 and 27.50\%, respectively; $p<0.01$ or $p<0.001)$ (Fig. $4 \mathrm{H})$ compared with negative controls. DEXA (positive control) reduced levels of TNF- $\alpha$ and IL- 6 by 23.05 and $30.14 \%$, respectively. 

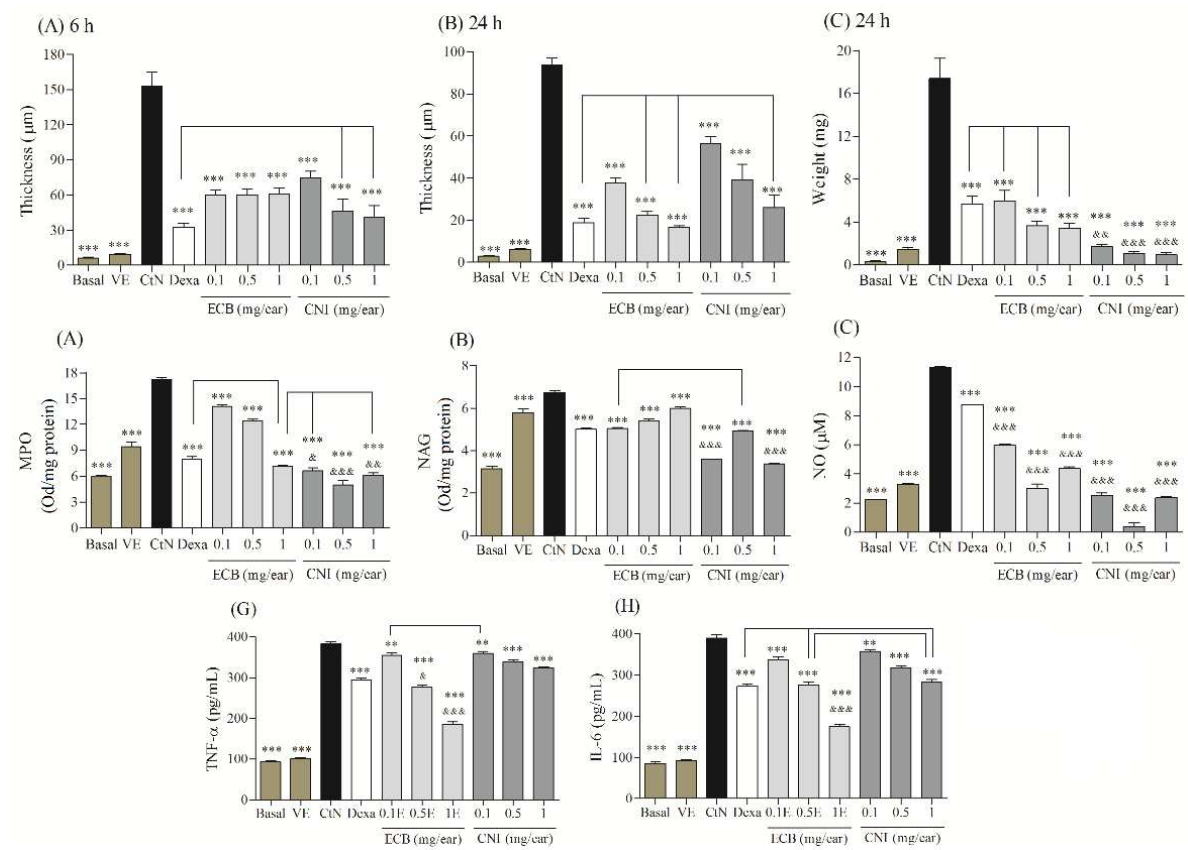

Fig. 2 Effect of ECB and CNI on croton oil-induced mouse ear edema and inflammatory markers. Each bar represents mean \pm S.E.M. $(n=8)$. (A) Thickness of ear after 6 hours; (B) Thickness of ear after 24 hours; (C) Weight of ear after 24 hours; (D) MPO activity; (E) NAG activity; (F) NO levels. (G) TNF- $\alpha$ levels; (H) IL-6 levels. VE, Vehicle; CtN, Control; Dexa, Dexamethasone; ECB, C. benedicta extract; MPO, Myeloperoxidase; NAG, N-Acetyl- $\beta$-D-glucosaminidase; CNI, Cnicin; NO, Nitric oxide; TNF- $\alpha$, Tumor necrosis factor $\alpha$; IL-6, Interleukin 6. ***p $<0.001$ in relation to the negative control group after ANOVA followed by post-hoc Student-Newman-Keuls test; ${ }^{\&} \mathrm{p}<0.05 ;{ }^{\&} \mathrm{p} p<0.01$; \&\&\& $<0.001$ in relation to dexamethasone after ANOVA followed by post-hoc Student-Newman-Keuls test.

\section{Histopathology}

Ear fragments obtained after induction of inflammation with croton oil were analyzed histopathologically to confirm findings from thickness and weight, myeloperoxidase, N-acetyl- $\beta$-Dglucosaminidase, and nitric oxide analyses. Representative sections from ears of negative control mice showed marked increases in thickness characteristic of edema induced by typical inflammatory processes. Edema was accompanied by significant presence of leukocytes and vasodilation (Fig. 3A). Treatment with ECB (1.0 mg/ear, Fig. 3C) and CNI (1.0 mg/ear, Fig. 3D) reduced ear thickness and suppressed leukocytes and vasodilation. The positive control, Dexa ( $0.1 \mathrm{mg} /$ ear), was also effective (Fig. 3B).

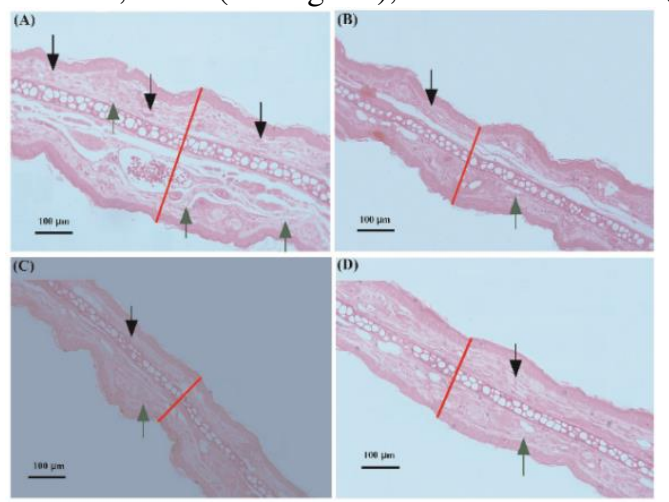

Fig. 3 Histological sections of representative ear fragments with edema induced by croton oil after treatment with ECB and CNI. Representative histological sections of mouse ears stained with hematoxylin-eosin (20×, $100 \mu \mathrm{m}$ scale). (A) Negative control; (B) Positive control (Dexamethasone); (C) ECB (1.0 mg/ear); (D) CNI (1.0 mg/ear); Black arrow down, Leukocytes; Green arrow up, Vasodilation; Red line, Thickness of edema.

Effects of ECB and CNI on AA, phenol, and capsaicin-induced mouse ear edema

Ear edema/inflammation induced by AA increased the thickness and weight of ears from negative control mice (Fig. 4A and 4B). ECB (23.30, 34.01, and 42.21\%) and CNI (16.72, 25.99, and 37.07\%) reduced edema thickness in a dose-dependent manner (Fig. 4A). This effect was reproduced in the 
assessment of ear weight, where ECB (40.75, 48.83, and 66.79\%) and CNI (17.41, 27.07, and 57.34\%) produced significant results ( $<$ 0.001) (Fig. 4B). IND, as a reference, significantly reduced ear thickness and weight $(\mathrm{p}<0.001)$. Further, effects of ECB $(0.1 \mathrm{mg} / \mathrm{ear})$ are not significantly different $(\mathrm{p}<0.05)$ from CNI (0.5 mg/ear) (Fig. 4A).

Phenol produced a significant increase in ear thickness and weight in negative control mice (Fig. 4C and 4D). ECB reduced this thickness (48.10, 54.10, and 55.10\%) and weight (51.20, 58.70 and 62.50\%) gain in a dose-dependent manner $2 \mathrm{~h}$ after treatment. Likewise, CNI reduced thickness by $35.30,47.60$, and $47.10 \%$ at doses of $0.1,0.5$ and $1.0 \mathrm{mg} /$ ear, respectively, and weight by $(65,80,72.40$ and $76.10 \%)$ in a dose-dependent manner. Dexa reduced thickness and weight by 71.80 and $56.40 \%$, respectively. Effects of ECB $(0.1 \mathrm{mg} /$ ear $)$ and CNI $(0.1,0.5$ and $1.0 \mathrm{mg} / \mathrm{ear})$ were similar, and effects of ECB $(0.5 \mathrm{mg} / \mathrm{ear})$ was similar to CNI $(0.5$ and $1.0 \mathrm{mg} / \mathrm{ear}, \mathrm{p}<0.05)$ (Fig. 4C). In addition, ECB (1.0 mg/ear) produced the same effect as CNI $(0.5 \mathrm{mg} / \mathrm{ear}, \mathrm{p}<0.05)$. ECB and CNI displayed the same effects as Dexa $(\mathrm{p}<0.05)$.
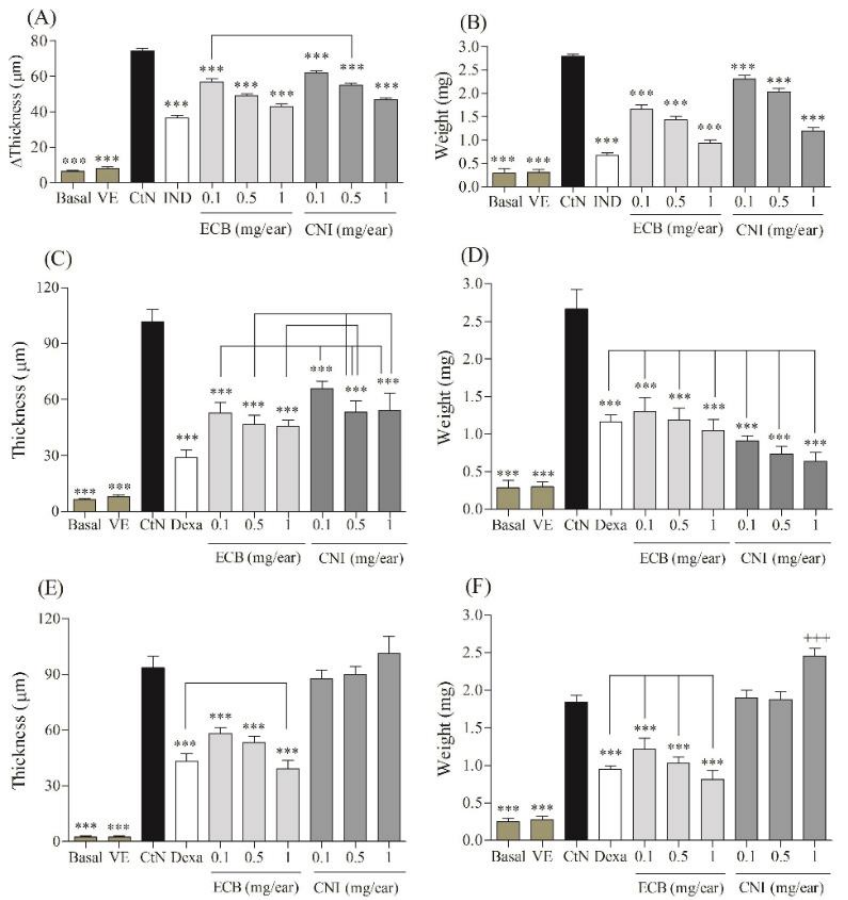

Fig. 4 Effects of ECB and CNI on arachidonic acid, phenol, and capsaicin-induced mouse ear edema. Bars represent means \pm S.E.M. $(\mathrm{n}=8)$. (A) and $(\mathrm{B})=$ Arachidonic acid-induced mouse ear edema; (C) and (D) $=$ Phenol-induced mouse ear edema; $(\mathrm{E})$ and $(\mathrm{F})=$ Capsaicin-induced mouse ear edema. VE, Vehicle; $\mathrm{CtN}$, Control; Dexa, Dexamethasone; IND, Indomethacin; ECB, C. benedicta extract; CNI, Cnicin. ***p $<0.001$ compared to negative controls. ${ }^{\&} p<0.05 ;{ }^{\& \&} p<0.01 ;{ }^{\& \& \&} p<0.001$ compared. ${ }^{+++} p<0.001$, mean was significantly higher than controls. Statistical calculations included ANOVA followed by post-hoc StudentNewman-Keuls test.

Induction of inflammation with capsaicin produced a significant increase in thickness and weight of ears of negative control mice $30 \mathrm{~min}$ after dermal application (Fig. 4E and 4F). ECB inhibited this increase in thickness by $37.75,43.11$, and $58.10 \%$ at doses of $0.1,0.5$ and $1.0 \mathrm{mg} / \mathrm{ear}$, respectively. ECB also inhibited weight gain by 34.01 ( $0.1 \mathrm{mg} / \mathrm{ear}), 44.24$ (0.5 mg/ear) and 55.80\% (1.0 mg/ear). However, CNI was not effective in reducing capsaicin-induced inflammatory processes. Conversely, CNI (1.0 $\mathrm{mg} / \mathrm{ear}$ ) potentiated the effect of capsaicin on weight gain. Dexa (positive control) was active in inhibiting the thickness and weight of edema (Fig. 4E and 4F). ECB (1.0 mg/ear) produced an effect similar to that of Dexa $(\mathrm{p}<0.05)$ in reducing thickness (Fig. 4E). All doses of CNI showed similar activity as Dexa (Fig. $4 \mathrm{~F})$.

Effects of ECB and CNI on histamine-induced mouse ear edema

Fifteen-minute ECB pretreatment $(0.1,0.5$, and $1.0 \mathrm{mg} / \mathrm{ear})$ significantly reduced ear thickness 2 $\mathrm{h}$ after intradermal administration of histamine; this effect was dose-dependent (Fig. 5). CNI pretreatment $(1.0 \mathrm{mg} / \mathrm{ear})$ inhibited histamine-induced edema $30 \mathrm{~min}$ after intradermal administration. This effect was also observed $90 \mathrm{~min}$ after injection for CNI $(0.1$ and $0.5 \mathrm{mg} / \mathrm{ear})(\mathrm{p}<0.05 ; \mathrm{p}<0.001)$. However, 0.1 $\mathrm{mg} /$ ear of CNI potentiated the effect of histamine at 60 and $75 \mathrm{~min}$ following histamine administration. Dexchlorpheniramine was more potent than Dexa in reducing edema, though both drugs were effective at all times evaluated (Fig. 5). 

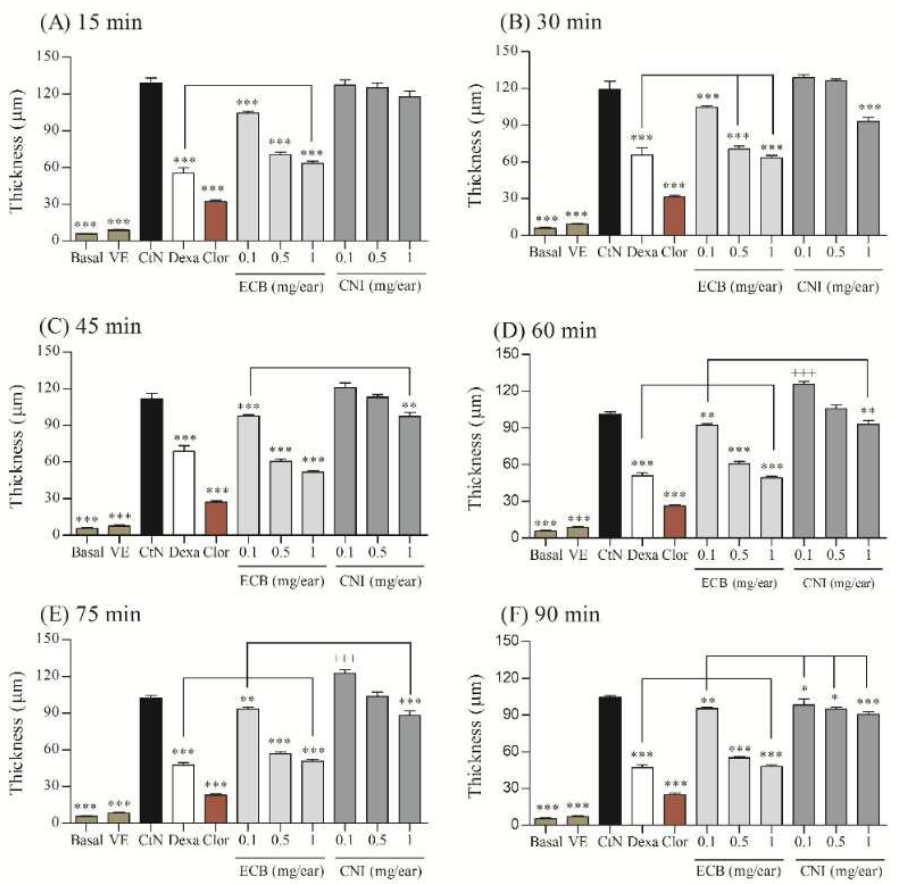

Fig. 5 Effects of ECB and CNI on the thickness of the histamine-induced mouse ear edema. Bars represent means \pm S.E.M. $(\mathrm{n}=8)$. Thickness was measured every $15 \mathrm{~min}$ after histamine application $(10 \mu \mathrm{L} /$ right ear). VE, Vehicle; CtN, Control; Dexa, Dexamethasone; Clor, Dexchlorpheniramine; ECB, C. benedicta extract; CNI, Cnicin. ${ }^{*} \mathrm{p}<0.05 ;{ }^{* *} \mathrm{p}<0.01$ and ${ }^{* * *} \mathrm{p}<0.001$ compared to negative controls. ${ }^{++} \mathrm{p}<0.001$, mean was significantly higher than controls. Statistics used ANOVA followed by post-hoc Newman-Keuls test.

ECB application (0.1, 0.5, and $1.0 \mathrm{mg} / \mathrm{ear})$ reduced ear weight compared to negative controls $(\mathrm{p}<$ 0.001) (Fig. 6). CNI inhibited ear weight gain at doses of 0.5 ( $\mathrm{p}<0.05$ ), and $1.0 \mathrm{mg} / \mathrm{ear}(\mathrm{p}<0.001)$. Both positive controls, Dexa and Clor, were effective in reducing ear weight (Fig. 6). ECB (0.5 and $1.0 \mathrm{mg} / \mathrm{ear}$ ) and CNI $(1.0 \mathrm{mg} /$ ear) produced an effect similar to that of Dexa $(\mathrm{p}<0.05)$, and ECB $(1.0 \mathrm{mg} /$ ear $)$ produced an effect similar to Clor for histamine-induced edema $(\mathrm{p}<0.05)$.

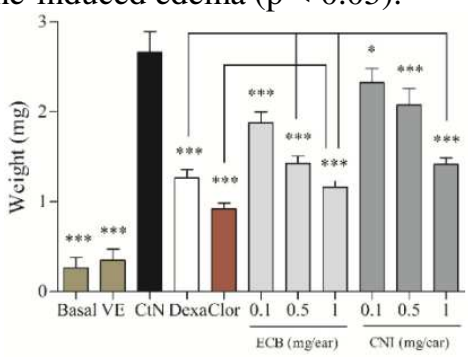

Fig. 6 Effects of ECB and CNI on the weight of mouse ears treated with histamine. Bars represent means \pm S.E.M. $(\mathrm{n}=8)$. Weight was measured $90 \mathrm{~min}$ after histamine application $(10 \mu \mathrm{L} /$ right ear $)$. VE $=$ Vehicle; $\mathrm{CtN}=$ Control; Dexa $=$ Dexamethasone $(0.1 \mathrm{mg} / \mathrm{ear}) ; \mathrm{Clor}=$ Dexchlorpheniramine $(0.1 \mathrm{mg} / \mathrm{ear}) ; \mathrm{ECB}=C$. benedicta extract; $\mathrm{CNI}=$ Cnicin. ${ }^{*} \mathrm{p}<0.05 ; * * \mathrm{p}<0.01$ and $* * * \mathrm{p}<0.001$ compared to negative controls. Comparisons used ANOVA followed by post-hoc Newman-Keuls tests.

Molecular docking study

Ligand structures were validated by redocking, which reproduced a crystallographic proteinbinder complex with a root-mean-square deviation of less than $2 \AA$. Ibuprofen, tolfenamic acid, I58, and dexamethasone interacted at binding sites of COX-1, COX-2, i-NOS, and glucocorticoid receptor (GCR), respectively, with an expressive reconstruction of crystallographic complexes. Conventional hydrogen bonding (Arg120 and Tyr353) was predicted with greater intensity for molecular interactions with COX-1 (ibuprofen) and COX-2 (tolfenamic acid). Interactions between I58 and induced NOS were also identified as conventional hydrogen bonding (Gln192, Tyr276, Gly300, Tyr302, and Glu306), and between dexamethasone and GCR were characterized by conventional hydrogen bonding among Asn67, Gln73, Arg114, Gln145, and Thr242, and carbon-hydrogen and alkyl bonding. 
Molecular interactions among CNI and COX-1, COX-2, i-NOS, and glucocorticoid receptor are shown in Fig. 8, and free energy (binding affinity) values in Table 1. Binding affinity of CNI for COX-1 was $-7.6 \mathrm{kcal}^{\mathrm{mol}} \mathrm{m}^{-1}$, a value equal to the affinity of the inhibitor, ibuprofen. Affinity for COX-2 was $-6,7$ kcal.mol ${ }^{-1}$, higher than ibuprofen $\left(-7.4 \mathrm{kcal}^{\mathrm{mol}}{ }^{-1}\right)$ and tolfenamic acid $\left(-9.0 \mathrm{kcal}^{\mathrm{mol}}{ }^{-1}\right)($ Table 1$)$. Thus, molecular interaction between CNI and COX-1 is as favorable as common pharmaceuticals. This interaction is due to conventional hydrogen bonds formed between ligand and enzyme (Fig. 7). CNI also interacts with COX-1 via carbon hydrogen, pi-donor hydrogen, and alkyl and pi-alkyl bonds.

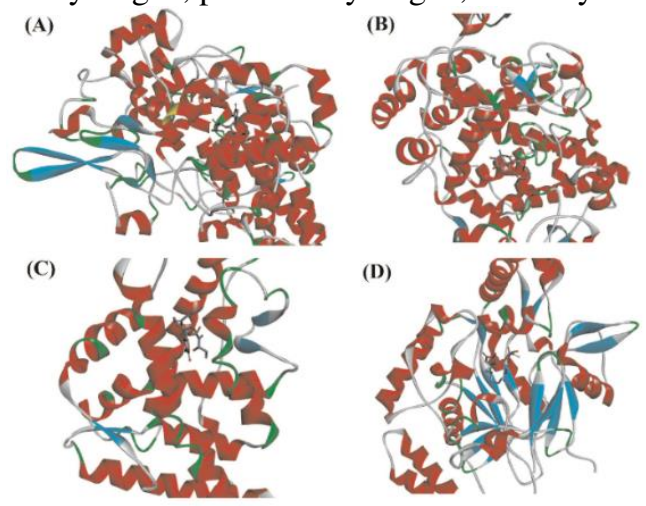

Fig. 7 Three-dimensional molecular orientation of CN1 at the molecular target-binding sites of COX1, COX2, GCR, and i-NOS. (A) Molecular interactions between CNI and COX-1; (B) COX-2; (C) glucocorticoid receptor (GCR); (D) induced nitric oxide synthase (i-NOS).

Molecular docking between CNI and induced nitric oxide synthase (i-NOS) suggests a lower binding affinity $\left(-7.4 \mathrm{kcal}_{\mathrm{mol}}^{-1}\right)$ than the reference inhibitor, I58 (-4.9 $\left.\mathrm{kcal}^{\mathrm{mol}}{ }^{-1}\right)$ (Table 1). The interaction profile showed conventional hydrogen bonding among Gln192, Tyr276, and Tyr302), a carbonhydrogen bond (Glu306) and, alkyl and pi-alkyl bonds (Val281 and Trp392). The lower binding affinity may reflect an ability of CNI to inhibit i-NOS. However, the affinity of CNI for GCR glucocorticoid receptor was $-7.3 \mathrm{kcal}_{\mathrm{mol}} \mathrm{m}^{-1}$, a value higher than for dexamethasone (Table 1). This result indicates an unfavorable interaction.

Table 1 Binding affinities between CNI and molecular binding targets. (-) Not tested. COX-1 (cyclooxygenase-1), COX-2 (cyclooxygenase-2); GCR (Glucocorticoid receptor); i-NOS (induced nitric oxide synthase).

\begin{tabular}{lcccc}
\hline Ligands & \multicolumn{4}{c}{ Binding affinity $\left(\mathrm{kcal}^{-\mathrm{mol}^{-1}}\right)$} \\
\cline { 2 - 5 } & COX-1 & COX-2 & i-NOS & GCR \\
\hline Ibuprofen & $-7,6$ & $-7,4$ & - & - \\
Tolfenamic acid & $-9,5$ & $-9,0$ & - & - \\
Dexamethasone & - & - & - & $-11,3$ \\
I58 & - & - & $-4,9$ & - \\
Cnicin & $-7,6$ & $-6,7$ & $-7,4$ & $-7,3$ \\
\hline
\end{tabular}

\section{Discussion}

Lack of effectiveness of drug treatment for some skin diseases encourages the search for new therapeutic agents with fewer adverse effects. This search remains a challenge, especially for natural products (Hahnel et al. 2017). The focus of this study was evaluation of CNI and ECB from C benedicta as topical anti-inflammatory agents using croton oil, Arachidonic acid (AA), phenol, capsaicin, and histamine as inducers of skin inflammation in mice. These agents are advantageous since they are associated with different inflammatory mechanisms and cause pathological conditions that mimic human and animal disease (Patil et al. 2019).

Due to the presence of TPA (12-O-tetradecanoylphorbol-13-acetate), the croton oil induces increased vascular permeability, vasodilation via histamine release, and migration of polymorphonuclear cells and macrophages with skin inflammation and cellular hyperproliferation that mimic skin pathologies, such as psoriasis (De Young et al. 1989). In addition, TPA upregulates gene expression of COX-2, lipoxygenase (LOX), and protein kinase $\mathrm{C}$ (PKC), and modulates several pro-inflammatory enzymes (COX-2 and i-NOS), pro-inflammatory proteins (IL-1, IL-2, IL-6, IL-8, TNF- $\alpha$ ), and adhesion molecules (Pungeró et al. 1998; Murakawa et al. 2006). Our results showed that, after topical application, ECB and CNI significantly reduced thickness and weight of mouse ears after induction of edema with croton oil (Figures 2A and 2B). CNI (0.5 and $1.0 \mathrm{mg} /$ ear) reduced ear thickness to an extent similar to Dexa six hours after treatment (Fig. 2A and 2B). Conversely, after 24 hours, the effects of ECB (0.5 and $1.0 \mathrm{mg} / \mathrm{ear})$ were 
potentiated or equal to Dexa (Fig. 2B and 2C). At this time, CNI was more potent than Dexa at all doses. So, as noted, 24 hours after treatment, variation in thickness and weight were dose-dependent for both agents, demonstrating that a single dose promotes less variation in the anti-inflammatory response. These agents can have mechanisms of action similar as glucocorticoids on nuclear receptors, since they may stimulate or inhibit protein synthesis (Ramamoorthy and Cidlowski 2016). Thus, various cellular functions are thus regulated, including actions of enzymes and synthesis of autacoids and cytokines (Ramamoorthy and Cidlowski 2016). Still, the anti-inflammatory activity of ECB and CNI may also be related to inhibition of other targets, which may provide additional benefits to patients with difficult-to-treat skin disorders, such as psoriasis and related pathologies (Chibli et al. 2014).

Vasodilation and leukocyte migration induced by croton oil is reflected in increased MPO activity that indicates the presence of polymorphonuclear cells (Bradley et al. 1982). A reduction in MPO values in tissues treated with ECB or CNI indicates inhibition of polymorphonucleated leukocytes (neutrophils) infiltration and suppression of inflammation. Also, ECB was as efficacious as Dexa, and CNI was even more potent ( $p<0.001$ ) (Fig. 2D), consistent with data presented in Fig. 2A, 2B, and 2C. Infiltration of mononuclear cells was indirectly quantified by assessing NAG activity (Mendes et al. 2009). ECB and CNI reduced the activity of this enzyme (Fig. 2E), indicating a decrease in mononuclear cells and vasodilation. CNI was more potent than Dexa (Fig. 2E), consistent with data presented in Fig. 2A, 2B, and 2C. Also, the release of NAG, a lysosomal enzyme involved in the generation of mediators, such as histamine, serotonin, cytokines, chemokines, and eicosanoids, is characteristic of the accumulation of mononuclear cells in ear edema induced by croton oil (Sánchez and Moreno 1999; Gábor 2003).

Nitric oxide (NO) is a small, simple molecule produced by the action of NO synthase (NOS). This enzyme displays two main types of isoforms, constitutive (c-NOS) and inducible (i-NOS) (Sobrevia et al. 2016). NO produced in endothelial cells diffuses rapidly into muscle cells and vascular lumens and promotes vasodilation. The chemical is involved in both physiological and pathophysiological processes (Mutchler and Straub 2015; Florentino et al. 2017). ECB and CNI reduced concentrations of NO in inflamed tissue (Fig. 2F), corroborating findings for MPO and NAG levels (Fig. 2D and 2E). Both ECB and CNI were more potent than dexamethasone in inhibiting the formation of NO, which may reflect inhibition of NOS (Fig. 2F). Again, these results are consistent with data for thickness, weight, MPO, and NAG parameters. All findings are consistent with the significant anti-inflammatory activity of ECB and CNI.

TNF- $\alpha$ is released at sites of inflammation and promotes activation of several cell types that release new cytokines and chemical mediators that expand the inflammatory process (Shinwan et al. 2019). Interactions with its receptors, TNFR1 or TNFR2, may activate nuclear transcription factor kappa B (NF$\mathrm{kB}$ ) and activating protein-1 (AP-1), as well as TNF- $\alpha$ can induce apoptosis, the formation of reactive oxygen species, and cell necrosis (Yang et al. 2018). In addition, IL-6 is a pro-inflammatory cytokine related to acute amplification of inflammation (Yang et al. 2018). ECB and CNI reduced levels of TNF- $\alpha$ and IL-6 (Fig. 2G and 2H), consistent with thickness and weight data and MPO, NAG, and NO findings (Fig. 2D-2F). These data also agree with findings of Schneider and Lachner (1987) that describe antiinflammatory effects of CNI from C. benedicta on rat paw edema.

Pronounced edema, vasodilation, and a greater number of leukocytes were observed in the ears of negative control mice (Fig. 3). Both ECB and CNI also reduced edema thickness, vasodilation, and leukocyte infiltration, consistent with physical and biochemical data for thickness and weight, MPO, NAG, NO, TNF- $\alpha$ and IL-6 (Fig. 3). ECB and CNI may act by mechanisms similar to Dexa, since is the latter agent is widely used as an adrenocorticoid, antiasthmatic, antiallergic, and anti-inflammatory drug for the treatment of dermatological disorders (Mehta et al. 2016).

AA was applied topically to stimulate prostaglandin production and, consequently, to induce ear edema with the formation of erythema, vasodilation, and leukocyte migration (Young et al. 1984; Doherty et al. 1988). ECB and CNI suppressed ear edema (thickness and weight) in a dose-dependent manner. However, ECB and CNI may also be associated with COX inhibition, since indomethacin, a non-selective COX inhibitor, inhibited the inflammatory process. Further, ECB showed similar effects to CNI, thus corroborating the croton oil-induced ear edema model.

Phenol causes changes in the skin that involve rupture of keratinocytes and release of IL-1 $\alpha$, IL-8, TNF- $\alpha, \mathrm{AA}$, and free radicals. It produces effects that mimic contact dermatitis in humans and animals (Lim et al. 2004; Murray et al. 2007). ECB and CNI counter the effects of phenol (Fig. 4), probably by inhibiting the generation of AA metabolites and/or free radicals. This finding is consistent with data from croton oil and AA models. Moreover, similar effects of ECB and CNI may reflect the cnicin content of ECB, although other ECB constituents may also be involved. These findings show that ECB and CNI might be effective against contact dermatitis.

Capsaicin promotes neurogenic inflammation through activation of transient receptor potential vanilloid 1 (TRPV1), a calcium-permeable channel. This activation promotes the release of neuropepitides (substance $\mathrm{P}$, peptides related to the calcitonin gene and tachykinins) and monoamines (serotonin and 
histamine) (Gábor and Rázga 1992; Inoue et al. 1993). As a consequence, signs of acute inflammation, such as vasodilation with increased blood flow and elevated local temperature, are triggered (Szolcsányi 1988). The topical application of ECB significantly reduced ear thickness and weight (Fig. 5A and 5B). Conversely, CNI was ineffective. A dose of $1.0 \mathrm{mg} / \mathrm{ear}$ actually potentiated the effect of capsaicin, as indicated by increased ear weight (Fig. 5B). Therefore, CNI does not block the action of capsaicin in activating TRPV1.

Histamine is a vasoactive amine released by activated mast cells. The amine promotes immediate hypersensitivity reactions related to the pathogenesis of various allergic diseases, such as atopic dermatitis, allergic rhinitis, and allergic asthma (Brand et al. 2002). These actions are mediated by HR1 receptors (Thangam et al. 2018) that promotes differential regulation of Th2 lymphocytes with cytokine secretion (IL-5, IL-4, IL-10, and IL-13) and Th1 with inhibition of $\gamma$-interferon (IFN- $\gamma$ ), IL-12, and IL-2. Histamine also induces the release of leukotrienes, cytokines, and chemokines (Jemima et al. 2014). ECB reduced ear thickness dose-dependently 15-90 min after histamine injection (Fig. 6). Interestingly, at 60 and 75 min after injection of histamine, CNI potentiated histamine action (Fig. 6D and 6E). Receptor ligands can affect the stability of active $\left(\mathrm{R}^{*}\right)$ and inactive $(\mathrm{R})$ states and function either agonistically or antagonistically (Thangam et al. 2018). A similar response was seen when assessing ear fragment weight. ECB produced a similar effect to dexchlorpheniramine. ECB constituents may act as an RH1 antagonist or inverse agonist. Drugs, such as glucocorticoids, cyclosporine, and cromoglycate, show inhibitory effects on mast cell degranulation and mediator release (Amin 2012).

The carboxylic acid group of AA interacts with the active site of COX-1 at Arg120 and Tyr355 residues through hydrogen bonding to promote the production of prostaglandins and other mediators Also, carbon 13 (double-bonded) of AA is close to the phenolic oxygen of Tyr385 with an orientation for $\mathrm{H}$ bonding (Marnett et al. 1999). Ibuprofen, a COX-1 inhibitor, hydrogen bonds with the Arg120 residue. CNI also bonds with COX-1 at $\operatorname{Arg} 120(\mathrm{OH}$ in $\mathrm{C} 15)$ and Ser530 (OH in $\mathrm{C} 4$ ') residues and via $\mathrm{C}-\mathrm{H}$ interactions at Tyr355 and Tyr385; the agent may act as a COX-1 inhibitor. The binding affinity of CNI (-7.6 $\mathrm{kcal}_{\mathrm{mol}}^{-1}$ ) for COX-1 is equal to the affinity of the reference compound, ibuprofen $\left(-7.6 \mathrm{kcal}^{\mathrm{mol}} \mathrm{m}^{-1}\right)$ (Table 1). Competition for the COX-1 active site might explain the inhibition of edema by CNI after induction by croton oil (Fig. 2A to 2C) and arachidonic acid (Fig. 4A and 4B). Such competition would inhibit prostaglandin production. Further, molecular docking indicated that CNI could inhibit inducible nitric oxide synthase (i-NOS) (Sobrevia et al. 2016). Inhibition might occur via hydrogen bonding with Gln192, Tyr276, and Tyr302 residues. The reference compound, I38 interacts in Gln192, Tyr 276, Gly300, Tyr302, and Glu306 by hydrogen bonding. Thus, inhibition of i-NOS could explain the reduction of NO levels shown in Fig. 2F.

Finally, topical anti-inflammatory effects of $C$. benedicta, may also involve the action of one or several other constituents present in the extract, such as polyphenols (Djamila et al. 2013). Phytochemical constituents, such as tannins and flavonoids, are recognized for their anti-inflammatory effects on wounds. Among the active compounds ECB, CNI is a primary constituent responsible for healing actions (Kataria 1995).

\section{Conclusion}

The anti-inflammatory properties of ECB (C. benedicta extract) and CNI (a sesquiterpene lactone) were demonstrated in experimental models of edema/inflammation. Mechanisms of action of these products are related to inhibition of one or more inflammatory response pathways. As an active compound, CNI is a promising anti-inflammatory agent for the treatment of skin diseases, such as psoriasis, contact dermatitis, and atopic dermatitis. The use of these agents may aid the development of new pharmaceutical and dermocosmetic products.

\section{References}

Alhadrami HA, Sayed AM, Hassan HM, Youssif KA, Gaber Y, Moatasim Y, Kutkat O, Mostafa A, Ahmed M, Rateb ME, Abdelmohsen UR, Gamaleldin NM (2021) Cnicin as an anti-SARS-CoV-2: An integrated in silico and in vitro approach for the rapid identification of potential COVID-19 therapeutics. Antibiotics 10:1-18. https://doi.org/10.3390/antibiotics10050542

Aljebab F, Choonara I, Conroy S (2017) Systematic review of the toxicity of long-course oral corticosteroids in children. Plos One 12:1-18. https://doi.org/10.1371/journal.pone.0170259

Al-Snafi AE (2016) The constituents and pharmacology of Cnicus benedictus - A review. Pharm Chem J 3:129-135.

Amin K (2012). The role of mast cells in allergic inflammation. Respir Med 106:9-14. https://doi.org/10.1016/j.rmed.2011.09.007 
Bach SM, Fortuna MA, Attarian R, Trimarco JT, Catalán CAN, Av-Gay Y, Bach H (2011) Antibacterial and cytotoxic activities of the sesquiterpene lactones cnicin and onopordopicrin. Nat Prod Commun 6:163166. https://doi.org/10.1177/1934578X1100600202

Bradley PP, Priebat DA, Christensen RD, Rothstein G (1982) Measurement of cutaneous inflammations: estimation of neutrophil content with an enzyme marker. J Invest Dermatol 78:206-209. https://doi.org/10.1111/1523-1747.ep12506462

Brand C, Townley SL, Finlay-Jones JJ, Hart PH (2002) Tea tree oil reduces histamine-induced oedema in murine ears. Inflamm Res 51:283-289. https://doi.org/10.1007/p100000305

Can Z, Baltas N, Keskin S, Yildiz O, Kolayh S (2017) Properties of antioxidant and anti-inflammatory activity and phenolic profiles of Şevketi Bostan (Cnicus benedictus L.) cultivated in Aegean Region from Turkey. Turk J Agr 5:308-314. https://doi.org/10.24925/turjaf.v5i4.308-314.1054

Chibli LA, Rodrigues KCM, Gasparetto CM, Pinto NCC, Fabri RL, Scio E, Alves MS, Del-Vechio-Vieira G, Sousa OV (2014) Anti-inflammatory effects of Bryophyllum pinnatum (Lam.) Oken ethanol extract in acute and chronic cutaneous inflammation. J Ethnopharmacol 154:330-338. https://doi.org/10.1016/j.jep.2014.03.035

Colorado A, Slama JT, Stavinoha WB (1991) A new method for measuring auricular inflammation in the mouse. J Pharmacol Methods 26:73-77. https://doi.org/10.1016/0160-5402(91)90056-b

De Young LM, Kheifets JB, Ballaron SJ, Young JM (1989) Edema and cell infiltration in the phorbol estertreated mouse ear are temporally separate and can be differentially modulated by pharmacologic agents. Agents Actions 26:335-341. https://doi.org/10.1007/BF01967298

Djamila C, Akym A, Faiza M, Chahinez B, Nacer-Bey N (2013) Anatomical, phytochemical and pharmacological studies of roots of Cnicus benedictus L. Int J Med Plants Res 2:204-208.

Doherty NS, Beaver TH, Rheins LA, Nordlund JJ (1988) Multiple topical applications of arachidonic acid to mouse ears induce inflammatory and proliferative changes. J Invest Dermatol 91:298-302. https://doi.org/10.1111/1523-1747.ep12475630

Erel SB, Karaalp C, Bedir E, Kaehlig H, Glasl S, Khan S, Krenn L (2011) Secondary metabolites of Centaurea calolepis and evaluation of cnicin for anti-inflammatory, antioxidant, and cytotoxic activities. Pharm Biol 49:840-849. https://doi.org/10.3109/13880209.2010.551538

Florentino IF, Silva DPB, Silva DM, Cardoso CS, Moreira ALE, Borges CL, Soares CMA, Galdino PM, Lião LM, Ghedini PC, Megenatti R, Costa EA (2017) Potential anti-inflammatory effect of LQFM-021 in carrageenan-induced inflammation: The role of nitric oxide. Nitric Oxide 69:35-44. https://doi.org/10.1016/j.niox.2017.04.006

Gábor M (2003) Models of acute inflammation in the ear. In: Winyard PG, Willoughby DA (ed) Inflammation protocols: Methods in molecular biology, Humana Press, Switzerland, 225, pp. 129137. https://doi.org/10.1385/1-59259-374-7:129

Gábor M, Rázga Z (1992) Development and inhibition of mouse ear oedema induced with capsaicin. Agents Actions 36:83-86. https://doi.org/10.1007/BF01991233

Green LC, Wagner DA, Glogowski J, Skipper PL, Wishnok JS, Tannenbaum SR (1982) Analysis of nitrate, nitrite, and [15n]nitrate in biological fluids. Anal Biochem 126:131-138. https://doi.org/10.1016/00032697(82)90118-x

Hahnel E, Lichterfeld A, Blume-Peytavi U, Kottner J (2017) The epidemiology of skin conditions in the aged: A systematic review. J Tissue Viability 26:20-28. https://doi.org/10.1016/j.jtv.2016.04.001

Inoue H, Nagata N, Koshihara Y (1993) Profile of capsaicin-induced mouse ear oedema as neurogenic inflammatory model: comparison with arachidonic acid-induced ear oedema. Br J Pharmacol 110:16141620. https://doi.org/10.1111/j.1476-5381.1993.tb14009.x

Jemima EA, Prema A, Thangam EB (2014) Functional characterization of histamine H4 receptor on human mast cells. Mol Immunol 62:19-28. https://doi.org/10.1016/j.molimm.2014.05.007

Jindal S, Jindal N (2018) Psoriasis and cardiovascular diseases: A literature review to determine the causal relationship. Cureus 10:1-7. https://doi.org/10.7759/cureus.2195

Jöhrer K, Obkircher M, Neureiter D, Parteli J, Zelle-Rieser C, Maizner E, Kern J, Hermann M, Hamacher F, Merkel O, Wacht N, Zidorn C, Scheideler M, Greil R (2012) Antimyeloma activity of the sesquiterpene lactone cnicin: impact on Pim-2 kinase as a novel therapeutic target. J Mol Med 90:681-693. https://doi.org/10.1007/s00109-011-0848-X

Karimkhani C, Dellavalle RP, Coffeng LE, Flohr C, Hay RJ, Langan SM, Nsoesie EO, Ferrari AJ, Erskine HE, Silverberg JI, Vos T, Naghavi M (2017) Global skin disease morbidity and mortality: An update from the global burden of disease study 2013. JAMA Dermatol 153:406-412. https://doi.org/10.1001/jamadermatol.2016.5538

Kataria H (1995). Phytochemical investigation of medicinal plant Cnicus wallichii and Cnicus benedictus L. Asian J Chem 7:227-228. 
Lim H, Park H, Kim HP (2004) Inhibition of contact dermatitis in animal models and suppression of pro inflammatory gene expression by topically applied flavonoid, wogonin. Arch Pharm Res 27:442-448. https://doi.org/10.1007/BF02980087

Lowry OH, Rosebrough NJ, Farr AL, Randall RJ (1951) Protein measurement with the Folin phenol reagent. J Biol Chem 193:265-275.

Marnett LJ, Rowlinson SW, Goodwin DC, Kalgutkar AS, Lanzo CA (1999) Arachidonic acid oxygenation by COX-1 and COX-2: mechanisms of catalysis and inhibition. J Biol Chem 274:22903-22906. https://doi.org/10.1074/jbc.274.33.22903

Mehta AB, Nadkarni N, Patil SP, Godse KV, Gautam M, Agarwal S (2016) Topical corticosteroids in dermatology. Indian J Dermatol Venereol Leprol 82:371-378. https://doi.org/10.4103/0378-6323.178903

Mendes BJ, Rocha MA, Araújo FA, Moura SAL, Ferreira MAND, Andrade SP (2009) Differential effects of rolipram on chronic subcutaneous inflammatory angiogenesis and on peritoneal adhesion in mice. Microvasc Res 78:265-271. https://doi.org/10.1016/j.mvr.2009.08.008

Mizuno H, Usuki T (2018) Ionic liquid-assisted extraction and isolation of cynaropicrin and cnicin from Artichoke and Blessed thistle. Chem Select 3:1781-1786. https://doi.org/10.1002/slct.201703063

Murakawa M, Yamaoka K, Tanaka Y, Fukada Y (2006) Involvement of tumor necrosis factor (TNF- $\alpha)$ in phorbol ester 12-o-tetradecanoylphorbol-13-acetate (TPA)-induced skin edema in mice. Biochem Pharmacol 71:1331-1336. https://doi.org/10.1016/j.bcp.2006.01.005

Murray AR, Kisin E, Casanova V, Kommineni C, Gunther MR, Shvedova AA (2007) Phenol-induced in vivo oxidative stress in skin: evidence for enhanced free radical generation, thiol oxidation, and antioxidant depletion. Chem Res Toxicol 20:1769-1777. https://doi.org/10.1021/tx700201z

Mutchler SM, Straub AC (2015) Compartmentalized nitric oxide signaling in the resistance vasculature. Nitric Oxide 49:8-15. https://doi.org/10.1016/j.niox.2015.05.003

Pasparakis M, Haase I, Nestle FO (2014) Mechanisms regulating skin immunity and inflammation. Nat Rev Immunol, 14:289-301. https://doi.org/10.1038/nri3646

Patil KR, Mahajan UB, Unger BS, Goyal SN, Belemkar S, Surana SJ, Ojha S, Patil CR (2019) Animal models of inflammation for screening of anti-inflammatory drugs: Implications for the discovery and development of phytopharmaceuticals. Int J Mol Sci 20:1-38. https://doi.org/10.3390/ijms20184367

Pungeró V, Turull A, Queralt J (1998) Arachidonic acid (AA) and tetradecanoylphorbol acetate (TPA) exert systemic effects when applied topically in the mouse. Inflammation 22:307-314. https://doi.org/10.1023/a:1022352200273

Queiroz LS, Ferreira EA, Mengarda AC, Almeida AC, Pinto PF, Coimbra ES, Moraes J, Denadai AML, Da Silva Filho AA (2021) In vitro and in vivo evaluation of cnicin from blessed thistle (Centaurea benedicta) and its inclusion complexes with cyclodextrins against Schistosoma mansoni. Parasitol Res 120:1321-1333. https://doi.org/10.1007/s00436-020-06963-2

Ramamoorthy S, Cidlowski JA (2016) Corticosteroids-mechanisms of action in health and disease. Rheum Dis Clin North Am 42:15-31. https://doi.org/10.1016/j.rdc.2015.08.002

Rendon A, Schäkel K (2019) Psoriasis pathogenesis and treatment. Int J Mol Sci 20:1-28. https://doi.org/10.3390/ijms20061475

Sánchez T, Moreno JJ (1999) Role of leukocyte influx in tissue prostaglandin H synthase-2 overexpression induced by phorbol ester and arachidonic acid in skin. Biochem Pharmacol 58:877-879. https://doi.org/10.1016/s0006-2952(99)00169-0

Sargent MG (1987) Fiftyfold amplification of the Lowry protein assay. Anal Biochem 163:476-481. https://doi.org/10.1016/0003-2697(87)90251-x

Schneider G, Lachner I (1987) A contribution to analytics and pharmacology of cnicin. Planta Med 53:247251. https://doi.org/10.1055/s-2006-962693

Shedoeva A, Leavesley D, Upton Z, Fan C (2019) Wound healing and the use of medicinal plants. Evid Based Complement Alternat Med 2019:1-30. https://doi.org/10.1155/2019/2684108

Shinwan K, Jan TV, Borna R (2019) Cytokines in inflammatory disease. Int. J. Mol. Sci. 20:1-31. https://doi.org/10.3390/ijms20236009

Silva BAF, Costa RHS, Fernandes CN, Leite LHI, Ribeiro-Filho J, Garcia TR, Coutinho HDM, Wanderley AG, Menezes IRA (2018) HPLC profile and antiedematogenic activity of Ximenia americana $L$. (Olacaceae) in mice models of skin inflammation. Food Chem Toxicol 119:199-205. https://doi.org/10.1016/j.fct.2018.04.041

Sobrevia L, Ooi L, Ryan S, Steinert JR (2016) Nitric oxide: A regulator of cellular function in health and disease. Oxid Med Cell Longev 2016:1-2. https://doi.org/10.1155/2016/9782346

Stewart JJ (2014) Optimization of parameters for semiempirical methods VI: More modifications to the NDDO approximations and re-optimization of parameters. J Mol Model 19:1-32. https://doi.org/10.1007/s00894-012-1667-x 
Szolcsányi J (1988) Antidromic vasodilatation and neurogenic inflammation. Agents Actions 23:4-11. https://doi.org/10.1007/BF01967170

Thangam EB, Jemima EA, Singh H, Baig MS, Khan M, Mathias CB, Church MK, Saluja R (2018) The role of histamine and histamine receptors in mast cell-mediated allergy and inflammation: The hunt for new therapeutic targets. Front Immunol 9:1-9. https://doi.org/10.3389/fimmu.2018.01873

Tiwana G, Fua J, Lu L, Cheesman MJ, Cock IE (2021) A review of the traditional uses, medicinal properties and phytochemistry of Centaurea benedicta L. Pharmacogn J 13:798-812. https://doi.org/10.5530/pj.2021.13.102

Trott O, Olson AJ (2010) Software news and update AutoDockVina: Improving the speed and accuracy of docking with a new scoring function, efficient optimization, and multithreading. J Comput Chem 31:455461. https://doi.org/10.1002/jcc.21334

Ulbricht C, Basch E, Dacey C, Hammemess P, Hashmi S, Seamon E, Vora M, Weissner W (2008) An evidence-based systematic review of blessed thistle (Cnicus benedictus) by the natural standard research collaboration. J Diet Suppl 5:422-437. https://doi.org/10.1080/19390210802519754

Yang S, Wang J, Brand DD, Zheng SG (2018) Role of TNF-TNF receptor 2 signal in regulatory T cells and its therapeutic implications. Front Immunol 9:1-13. https://doi.org/10.3389/fimmu.2018.00784

Young JM, Spires DA, Bedord CJ, Wagner B, Ballron SJ, Young LM (1984) The mouse ear inflammatory response to topical arachidonic acid. J Invest Dermatol 82:367-371. https://doi.org/10.1111/15231747.ep12260709

Zhang X-J, Wang A-P, Shi T-Y, Zhang J, Xu H, Wang D-Q, Feng L (2019) The psychosocial adaptation of patients with skin disease: a scoping review. BMC Public Health 19:1-15. https://doi.org/10.1186/s12889-019-7775-0

\section{Statements and Declarations}

Funding

This study was supported by Fundação de Amparo à Pesquisa do Estado de Minas Gerais (FAPEMIG, Grant numbers PPM 00296/16), Coordenação de Aperfeiçoamento de Pessoal de Nível Superior (CAPES), Conselho Nacional de Desenvolvimento Científico e Tecnológico (CNPq), and Pró-Reitoria de Pesquisa, Pós-Graduação e Inovação da Universidade Federal de Juiz de Fora.

Competing Interests

The authors have no relevant financial or non-financial interests to disclose

Author Contributions

All authors contributed to the study conception and design. Material preparation, data collection and analysis were performed by Guilherme Cabral Gonçalves, Lucas Sales Queiroz, Everton Allan Ferreira, Bruna Celeida Silva Santos, Ademar Alves da Silva Filho and Alex Gutterres Taranto. Th first draft of the manuscript was written by Orlando Vieira de Sousa and all authors commented on previous versions of the manuscript. All authors read and approved the final manuscript.

Data Availability

The datasets generated during and/or analysed during the current study are available in the Guilherme Cabral Gonçalves repository, https://repositorio.ufjf.br/jspui/handle/ufjf/11111.

Ethical approval

This study was performed in line with the principles of the Declaration of Helsinki and it was conducted in accordance with the Ethical Principles in Animal Research adopted by Brazilian Council for Control of Animal Experimentation (CONCEA). Approval was granted by the Ethics Committee of Federal University of Juiz de Fora (August 21, 2018/protocol number 022/2018).

Conflict of interest

The authors declare no conflict of interest. 